This manuscript is a non-peer reviewed preprint submitted to EarthArXiv. Please feel free to contact any of the authors; we welcome feedback

\title{
Toward the understanding of saline water intrusion and nutrient flushing in Lake Nokoué
}

\author{
Metogbe B. Djihouessi a, b,*, Rita Houngue a , Firmin Adandedji c, Luc Sintondji ${ }^{d}$ \\ a Laboratoire des sciences et technique de l'Eau, Benin ; \\ b Chaire UNESCO Sciences technologie et Environnement, Benin ; \\ c Laboratoire d'Hydrologie Appliquée, Université d'Abomey Calavi ; \\ d Laboratoire d'Hydraulique et de Maitrise de l'Eau, Université d'Abomey Calavi ; \\ * Corresponding author email: d.belfrid@aims.edu.gh. Phone: +229 97381845.
}

\begin{abstract}
To understand the salinity dynamic at the outlet of Lake Nokoué and to simulate the nutrient flushing from this lake into the Atlantic Ocean, a 2D hydrodynamic model was designed with Mike 21. The Hydrodynamics (HD) module simulated water level variations and flows in response, while the ECO-Lab module has been used for water quality modelling. The data used covered the hydrological period of 2013. The results from the HD simulation indicated that for a flow of $725 \mathrm{~m} / \mathrm{s}$ at Bonou on the Ouémé River, a tributary of Lake Nokoué. $70 \%$ of the land in the delta of Ouémé, between the Ouémé River and the So River (also a tributary of Lake Nokoué), are flooded against $90 \%$ for a river flow of $1100 \mathrm{~m}^{3} / \mathrm{s}$. The water level in the delta showed a water increase of $0.6 \mathrm{~m}$, in seven days, for a water flow of $725 \mathrm{~m}^{3} / \mathrm{s}$ at Bonou and a water increase of $1.3 \mathrm{~m}$, in seven days, for a water flow of $1100 \mathrm{~m}^{3} / \mathrm{s}$ at Bonou. Water quality simulations indicated that the seawater intrusion from the Atlantic Ocean into Lake Nokoué occurred from the bottom to the surface towards the surface of the lake. During flooding, despite the large inflow of fresh water, more than $60 \%$ of the water at the bottom of the lake had concentrations greater than 8. Simulation of the dispersion of nutrient point source pollution indicated that there was an accumulation of pollution at the bottom of the lake during low water periods. This accumulation increases in amplitude as one moves away from the Atlantic Ocean towards the north of the lake. In this period tidal flushing evacuated about $20 \%$ of the pollution ejected. In the high water period, about $70 \%$ of the pollution ejected in the lake was automatically flushed out in the lake the Atlantic Ocean.
\end{abstract}

Keywords: Hydrodynamic simulation; Coastal Lake; Lake Nokoué; West Africa

\section{Introduction}

The interest in the management of coastal lagoons and lakes in developing countries is increasing. The factors leading to this situation include: (i) the significant decrease in the ecosystem services that these resources produce leading to socio-economic challenges, (ii) the disturbance and loss of biodiversity heritage and, (iii) the increasing impact of rising sea level and climate change on the coastline, where are most of the politic and economic capital cities of these countries. However, although biophysical science has developed several tools for informing decision-makers (Jakeman et al., 2018; Fu et al., 2019), the use of these tools in developing countries face the main challenges of lack of inputs data. In fact, there is a limited number of aquatic ecosystems in sub-Saharan Africa where water level, hydrochemistry, environmental tracer, and geophysical information have been intensively collected to allow effective use of explanatory and predictable models.

Over the years, various approaches have been developed for modeling the water quality of aquatic ecosystems in data-limited contexts. These methods mostly rely on the use of alternative data sources such as satellite images or simulation results from other models. This led to the increasing number of efforts focusing on case studies and improvements of existing models and techniques, rather than addressing 
further fundamental research or challenging water quality issues that remain difficult to solve. However, it is important to keep in mind that the purpose of these approaches is to build models which can briefly explain the functioning of aquatic systems with limited data and to progressively improve these models by replacing parts of the model with new scientific modules as new data become available.

For Lake Nokoué, a coastal lagoon located in West Africa, one of the major challenges lies in understanding the saline intrusion from the Atlantic Ocean, and in predicting the diffusion of nutrients from tributary rivers. The Lake is in the delta of Ouémé river, has three tributaries namely Ouémé River, Sô River and Djonou River and is permanently connected to the Atlantic Ocean through the Channel of Cotonou which is his major outlet. Each year, lake Nokoué undergoes successive phases of fresh water and saline water respectively controlled by the water input from the tributaries during the flood period and the amplitude of the tide. (Le Barbé et al. 1993; Mama et al., 2011; Zandagba et al., 2016 ; Djihouessi and Aina, 2018). Therefore, a numerical modelling approach was developed to understand the salinity dynamic at the outlet of Lake Nokoué and to simulate the nutrient flushing from the lake into the Atlantic Ocean. Thus, a specific model was designed for the lake based on Mike 21 from the DHI group. MIKE 21 is a two-dimensional mathematical model (the 3D model being Mike 3) which simulate water flow, waves, water quality and sediments dynamics in lakes, estuaries, bays, coastal areas, and seas. Mike 21 has been chosen because of the long practice of the decision-makers in Benin with this software. This paper presents the result the results of the calibration of both the saline water intrusion model and the nutrient dispersion model using Mike 21 and Ecolab.

\section{Material and methods}

The model is based on a finite volume method used on an unstructured mesh to solve the two-dimensional incompressible Reynolds averaged Navier-Stokes's equations, subject to the assumptions of Boussinesq and hydrostatic pressure. The basic computational component of MIKE 21, Mike 3 is the hydrodynamic (HD) module which provides the basis for computations performed in the other module. The HD module simulates water level variations and flows in response to a variety of forcing functions in lagoons, estuaries and coastal regions.

\subsection{HD module Set up}

The MIKE21 FM model (flexible mesh) of Lake Nokoué has been established to simulate the water discharge of the lake into the Atlantic Ocean. The modelled domain extends in the sea from Lagos in the East to Lomé in the West. The lake receives water inputs from its two main tributaries (the Ouémé River and the So River). An unstructured finite-volume model domain having 15229 elements with 8099 nodes was prepared, covering Lake Nokoué with the Porto-Novo lagoon, the channel of Cotonou and the part of the Benin marine area (Figure 1). The domain was discredited by the subdivision of the continuum into nonoverlapping cells. An approximate Riemann solver was used for convective fluxes, which allow handling the discontinuous solutions. A Runge Kutta 4th order was used for the time integration.

The data used for the construction of the model included:

1. Topographic data from SRTM 90m (Figure 2)

2. The bathymetry data of the lake and the channel of Cotonou (Figure 1).

3. Offshore boundary conditions data at the Benin coast and tidal boundary conditions data in Lagos and Lomé, both generated by the C-MAP digital data services. These data were provided by the national institute of water (INE) and cover the period of Mars 2013 to June 2013 (Figure 3). This period corresponds to the slight raising water period when the water rainfalls over the Delta of Ouémé induces the increase of the water level in the lake (see section 3.1.3). The numerical modelling in this research only considers the period of April to July since tidal boundary conditions data for the rest of the hydrological period were not available.

The altimetry reference used in the model is the one from the "Institut Géographique National du Benin" (IGN Benin) which indicates the zero level of the country. The C-MAP marine data are referenced to the hydrographic zero $(\mathrm{ZH})$ which is located at $-0.535 \mathrm{~m}$ IGN. This data (negative depths) was therefore 
corrected by adding $-0.535 \mathrm{~m}$ to bring it to the IGN reference point. The average sea level is $+0.93 \mathrm{ZH}$. Offshore theoretical tide data is generated relative to the mean level and therefore was corrected by +0.395 $\mathrm{m}$ to be referenced to the IGN level. The water supply of the Ouémé River and So River were defined in the model as an upstream boundary condition of the modelled domain, located upstream of the lake. The daily flow for the modelling period was not available. Therefore, the average daily flow was calculated based on data from 1960 to 2011 for the Ouémé River, and 1960 to 1984 for the Sô River. The salinity data available used were the ones collected during the water sampling phase.

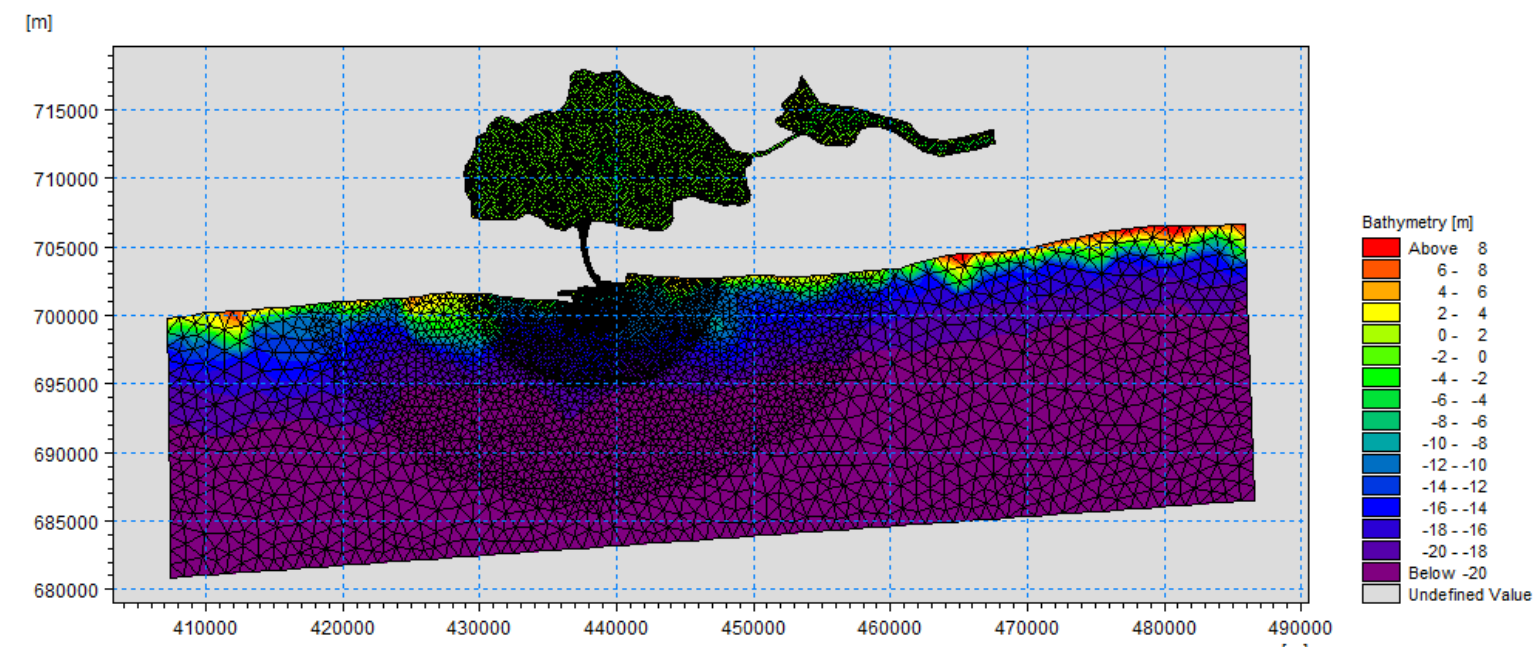

Figure 1: Mesh of the HD module of Lake Nokoué using Mike 21.

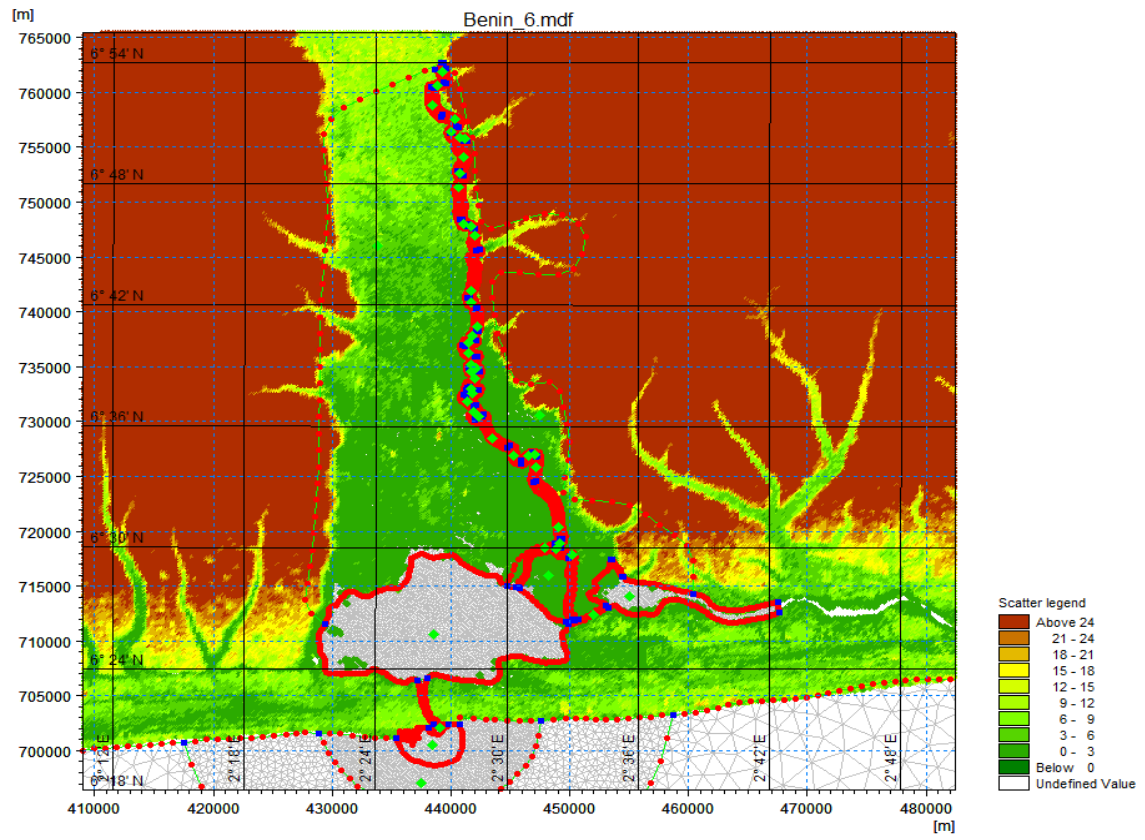

Figure 2: The 90m SRTM topographic data.

\subsection{Water quality module set up}

The objective here was to model the fate of conservative and non-conservative releases for several preidentified sources of pollution in Lake Nokoué. The simulations were performed considering pollution loaded in Ganvié and Cotonou, with an identical pollutant flow, allowing the comparison of the influence of the water current on the fate of the pollutant. The effect of the southwest wind has also been tested.

ECO Lab module in Mike 21 is being used for water quality modelling which solves the set of differential equations describing the physical, chemical and biological interactions involved in the degradation of 
organic matter, resulting in oxygen conditions and excess levels of nutrients in Nokoué lake waters. In this study, three water quality variables DO, Nitrate and Phosphate were considered. Initial values for the state variable are estimated from measurements data. The forcings like Temperature (temp, degree $\mathrm{C}$ ), Salinity (ppt), Water depth actual layer (meter), Wind speed $(\mathrm{m} / \mathrm{s})$ and Horizontal current speed $(\mathrm{m} / \mathrm{s})$ were input from the field observations and have been transferred from the hydrodynamic module to ECO Lab processing in Mike 21. There were 39 constants, 9 auxiliary variables and 21 processes, used as arguments in the differential equations that ECO Lab solves to determine the state of the state variables were included. The water quality model solves the system of differential equations that describe the chemical and biological states of the coastal waters. The Runge Kutta 4th Integration Method was considered for solving the ECO Lab differential equations.
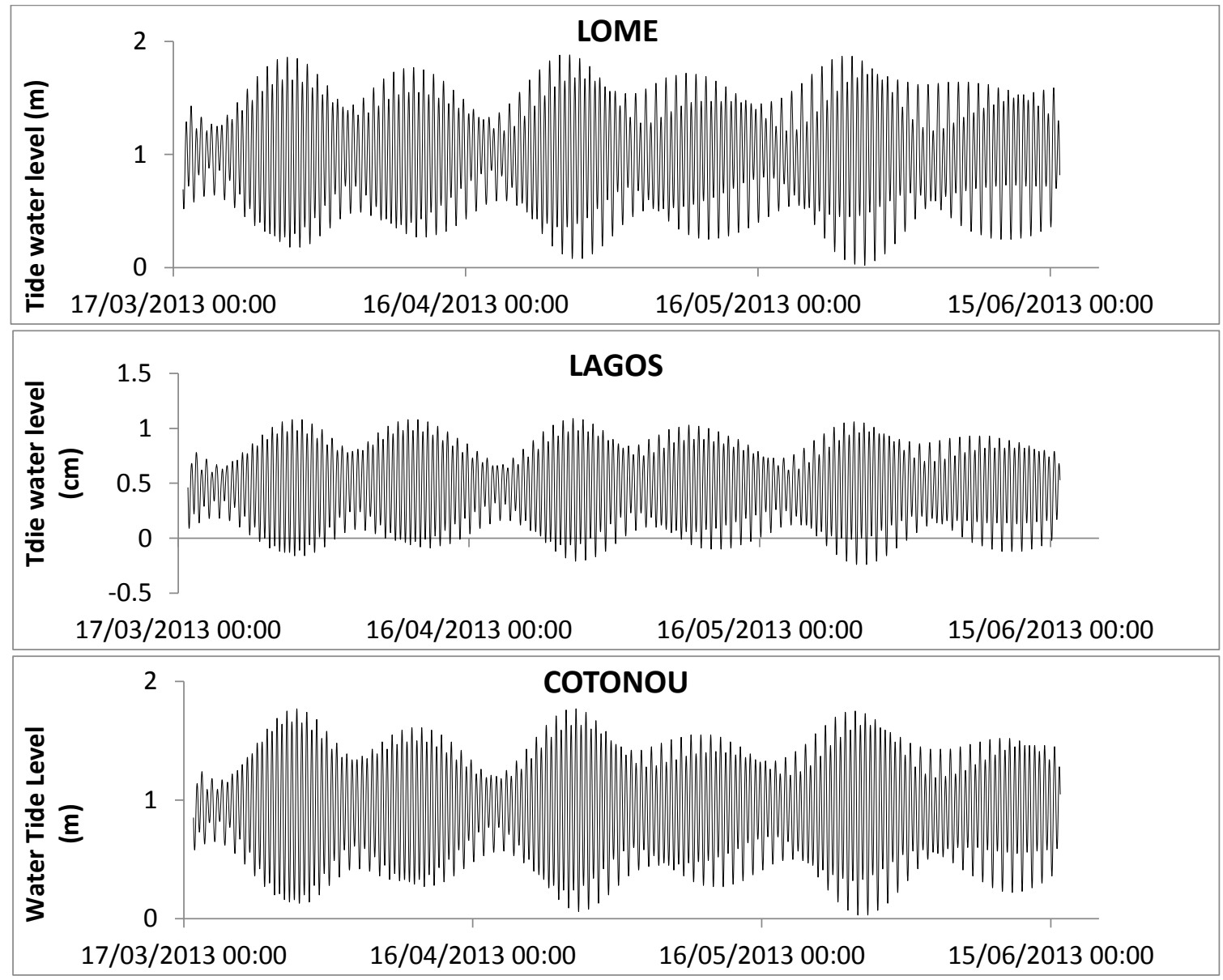

Figure 3: Tides curves of water in Lomé, Lagos and Cotonou during March-June 2013.

\section{Results and discussion}

\subsection{Hydrodynamics modelling}

The hydrodynamic module of the Mike 21 model was applied to simulate the water level variation of Nokoue Lake. Since the bathymetry of the tributary rivers (the Ouémé River and the So River) was not available, it was considered an average depth of $2 \mathrm{~m}$ for the Ouémé River and $4 \mathrm{~m}$ for the river Sô based on field measurements. The width of the rivers was digitized from Sentinel-2A satellite images in QGIS. Simulations were made two levels of water discharge: a water discharge of $725 \mathrm{~m}^{3} / \mathrm{s}$ at Bonou (representing the maximum flow rate for a 1 year return time) and a constant water discharge of $1100 \mathrm{~m}^{3} / \mathrm{s}$ at Bonou, (representing the maximum flow rate for a 10 year return time which caused the 2010 floods in the delta of the Ouémé). The results of the simulations are shown in Figure 4 and Figure 5. These results indicate that for a flow of $725 \mathrm{~m}^{3} / \mathrm{s}$ at Bonou, $70 \%$ of the land between the Ouémé River and the So River in the delta of Ouémé are flooded against $90 \%$ of the land flooded for a river flow of $1100 \mathrm{~m}^{3} / \mathrm{s}$. 


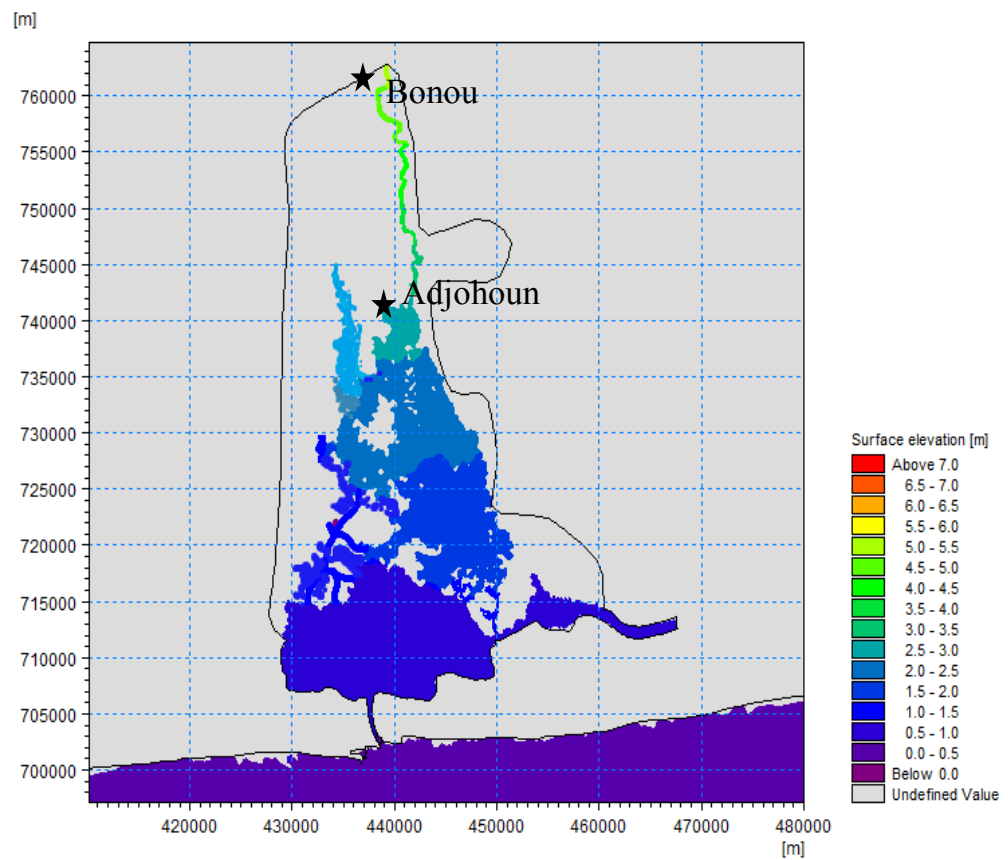

Figure 4: Water level simulation in the Ouémé delta after 10 days of constant water discharge of $725 \mathrm{~m}^{3} / \mathrm{s}$ at Bonou

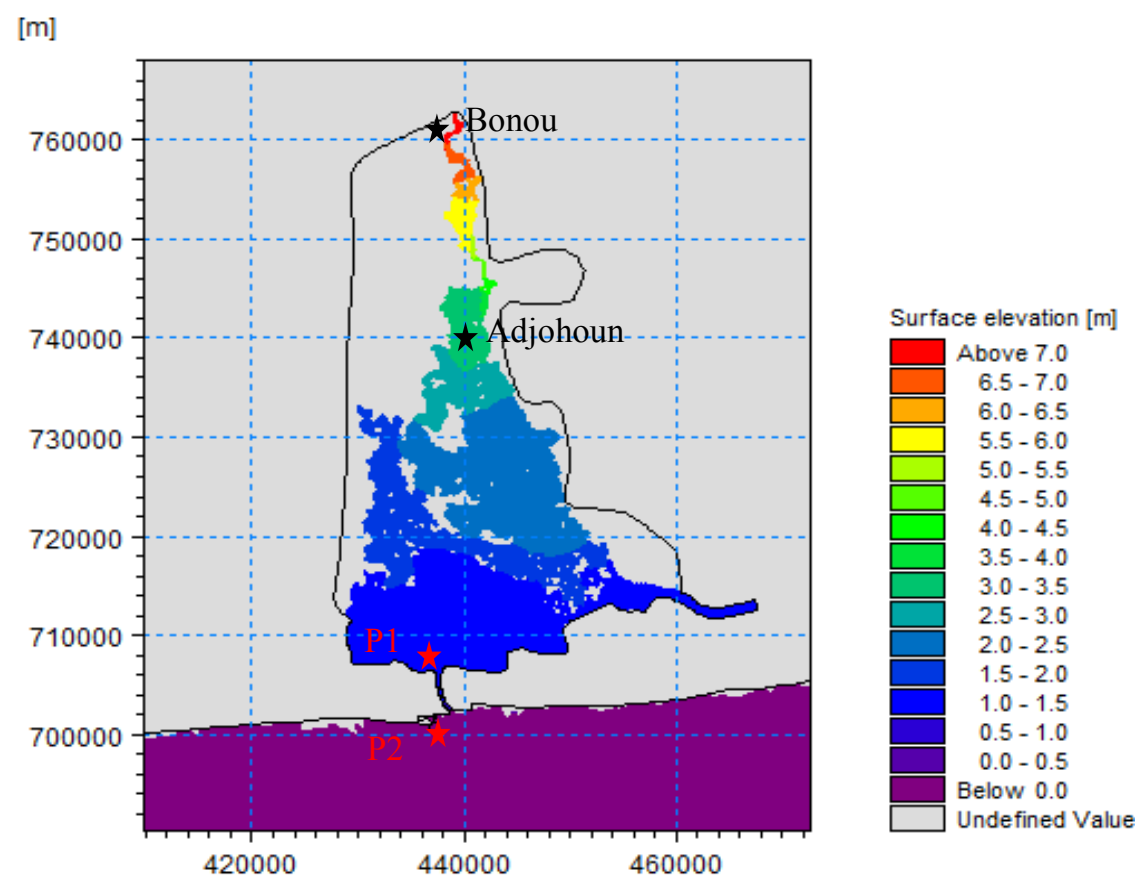

Figure 5: Water level simulation in the Ouémé delta after 10 days of constant water discharge of $1100 \mathrm{~m}^{3} / \mathrm{s}$ at Bonou.

The temporal evolution of the water flow was observed respectively at the entry of the outlet of the lake (P1) and the exit of the channel of Cotonou (P2) connected to the Atlantic Ocean. The water level showed that there was a water increase of $0.6 \mathrm{~m}$, in seven (7) days, for a water flow of $725 \mathrm{~m}^{3} / \mathrm{s}$ at Bonou and a water increase of $1.3 \mathrm{~m}$, in seven (7) days, for a water flow of $1100 \mathrm{~m}^{3} / \mathrm{s}$ in Bonou (Figure 6). The value of $0.6 \mathrm{~m}$ was close to the annual fluctuations (of $0.55 \mathrm{~m}$ ) observed in the water level of Lake Nokoué. The 1.3 $\mathrm{m}$ are close to the rising water recorded in the lake during the 2010 floods (between 1.29 and $1.34 \mathrm{~m}$ ). The additional information provided by the hydrodynamic model was 7 days which is required for the rise of the flood in Lake Nokoué. During floods, the water level of the lake dominated the tide during the water rising water period in the lake. This observation could justify the change in salinity which happened when the water level increased and confirmed that the flushing of the lake into the Atlantic Ocean is governed by its tributaries inputs. 


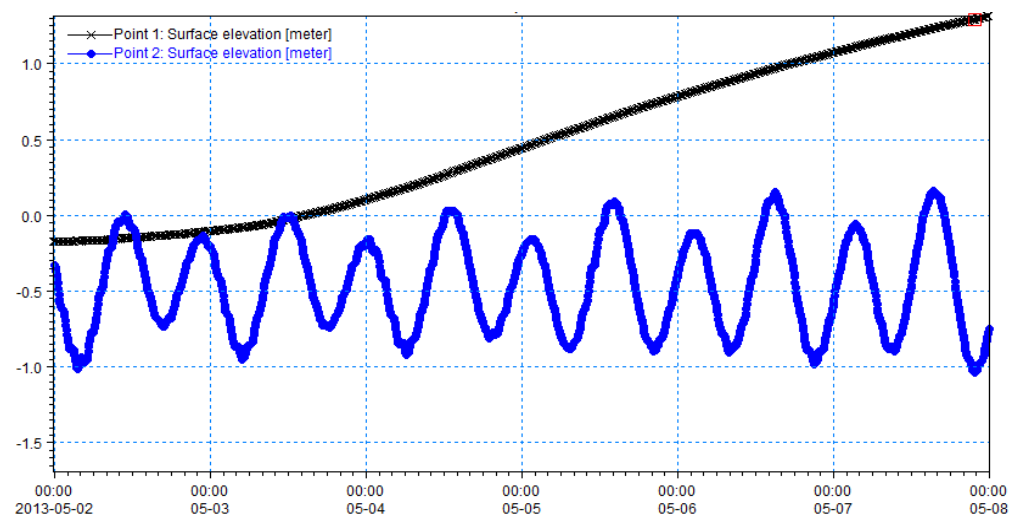

Figure 6: Temporal evolution of water level of Lake Nokoué (black) vs water level of Atlantic Ocean (blue) in low tide

The flushing simulated in the previous section considered low tide conditions from the Atlantic Ocean with a constant extreme water discharge of $1100 \mathrm{~m}^{3} / \mathrm{s}$ (Figure 7). Considering now a sea-level rise of $80 \mathrm{~cm}$ with of water discharge of $1100 \mathrm{~m}^{3} / \mathrm{s}$ at Bonou, the levels in the lake increase by $2 \mathrm{~m}$ after 8 days instead of $1.3 \mathrm{~m}$ initially. The flood map shows an increase of water level above $1 \mathrm{~m}$ throughout the northern area of the lake in the delta of Ouémé (Figure 8).

It is important to note here that several elements were not considered for the hydrodynamics simulations conducted here in this study. These elements include the acadja, and the pillar of the Ganvie houses are susceptible to influence the hydrodynamics of the lake. It is, therefore, necessary to map the acadja in the lake and to monitor their evolution in time. The simulations made here should be considered as a first approximation showing the overall hydrodynamic functioning of the system. More in-depth analyses have to be carried out by integrating data collected simultaneously (at the same dates) including data collected from the rivers bathymetry and the data on the connection of the delta with the Ouémé catchment.

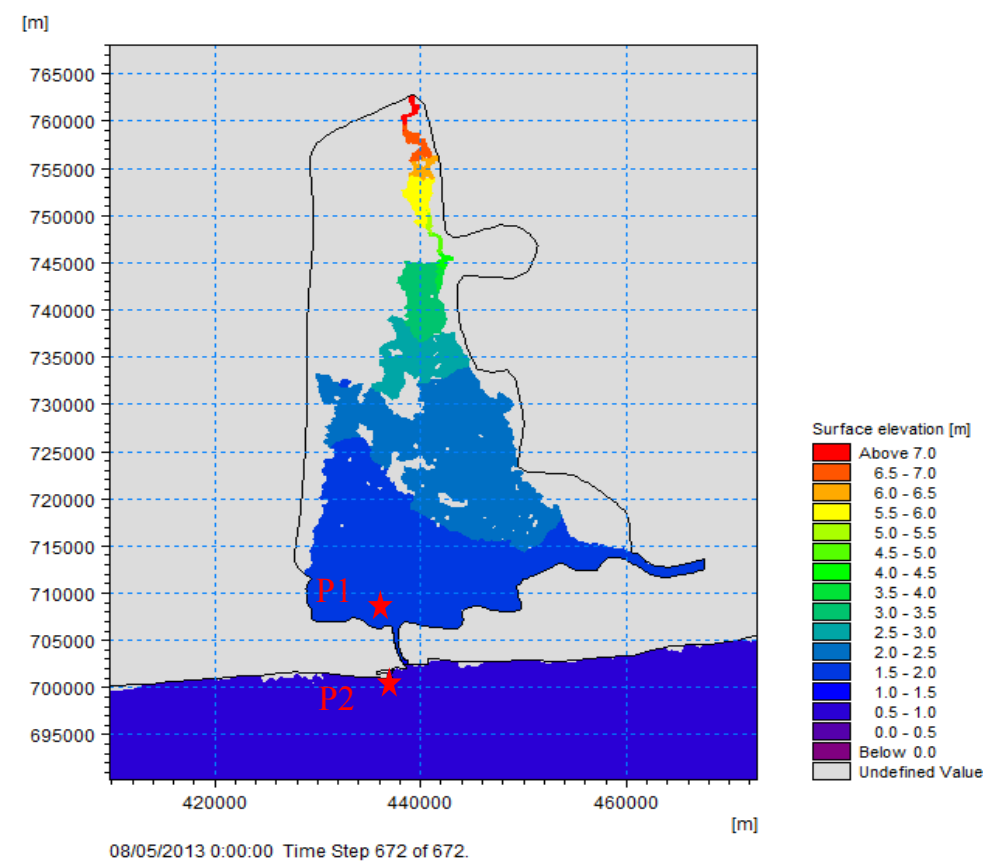

Figure 7: Simulation of water level in the delta of Ouémé after 10 days of constant water discharge of $1100 \mathrm{~m}^{3} \mathrm{~s}$ at Bonou, with a sea-level rise of $80 \mathrm{~cm}$. 


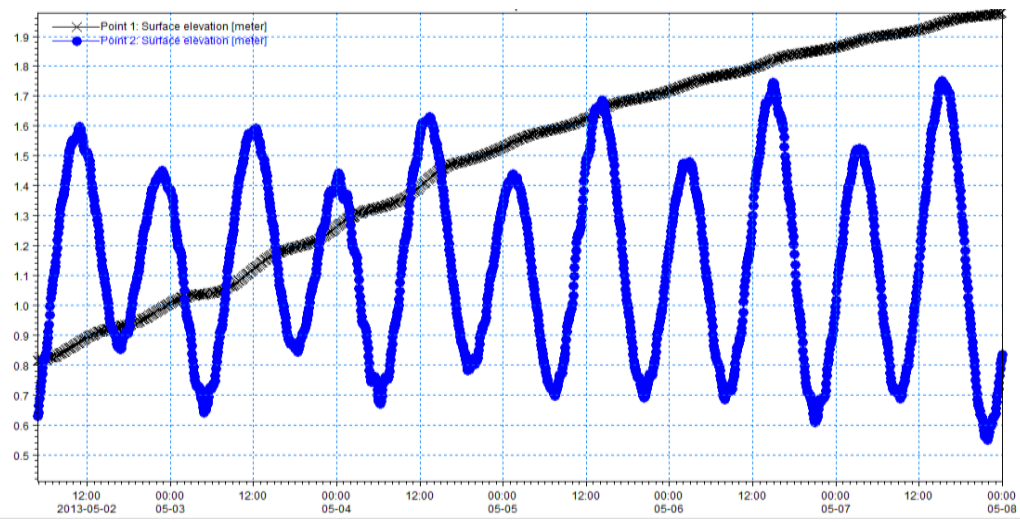

Figure 8: Temporal evolution of water level of Lake Nokoué (black) vs water level of Atlantic Ocean (blue) with a sea-level rise of $80 \mathrm{~cm}$.

\subsection{Saline water intrusion in the lake}

Figures 9A and 9B illustrate the saline water intrusion phenomenon in Lake Nokoué. Simulations were made for the high-water period at high tide, without the influence of wind, with and without the influence of turbulence. The results obtained indicate that no saline water intrusion occurs in the surface layer of the lake (Figure 9A). The seawater intrusion extends over the entire surface of the Channel of Cotonou, and its influence stops at the junction between the channel and the lake. The salinity in the bottom lake indicates an intrusion of seawater from the Channel of Cotonou to the north of the lake at Houedo-Gbadji and Dekanmè (Figure 9B). The salinity concentration gradient decreases as one moves away from the Channel of Cotonou and with salinity values decreasing from $30 \mathrm{ppt}$ (Cotonou Channel) to $12 \mathrm{ppt}$ (Houedo Gbadji). The salinity values in the bottom of the western part (Djonou) and the eastern part (Totchè) of the lake are almost null. This indicates that the salinity gradient in the bottom of the lake is north-south with very little propagation in the west and east directions.

In non-turbulence conditions, the salinity concentration profile was stratified, meaning there was no mixing between the seawater and the freshwater (Figure 10A). Both in the lake and the channel of Cotonou, there was a clear demarcation between the high saline waters at the bottom of the lake, with a thickness of about $50 \mathrm{~cm}$, and the freshwaters at the surface. A freshwater breakthrough occurred in the Cotonou Channel between the saline water surface and the saline bottom water (Figure 10A). The non-turbulence condition corresponds to the phase where the water in the lake and the tide flow in the same direction, which is the north-south direction. During this period, simultaneous development of freshwater (surface) and marine (bottom) species might occur in the lake. In turbulent conditions (Figure 10B), where the lake and the tide flow in the opposite direction, there is a total mixture of these waters in the channel of Cotonou, resulting in high salinity concentrations in the channel. However, the stratification observed in the lake in nonturbulence conditions was also observed in turbulent conditions, with an increase in the thickness of the bottom saline water layer from 50 to about $80 \mathrm{~cm}$ (Figure 10B). Only saline water species can be present in the channel in turbulent conditions while in the lake, freshwater species can be found in the surface layer (up to $80 \mathrm{~cm}$ depth).

\subsection{Nutrients point source dispersion in Lake Nokoué}

Two-point sources of nutrient ejection were considered for the simulations. The first point source was placed in the village of Ganvié because of the constant rejection of wastewater and solid waste into the water column. The second point considered was near the channel of Cotonou because this location is the outlet of two storm-water collectors which pass through the Dantokpa market (the biggest market in the country). It was assumed that the nutrient ejection occurred at the surface of the lake and reached the bottom of the lake through the influence of gravity and the water velocity occurring at the points. The nutrient ejection was considered constant all over the simulation period. 
$[\mathrm{m}]$
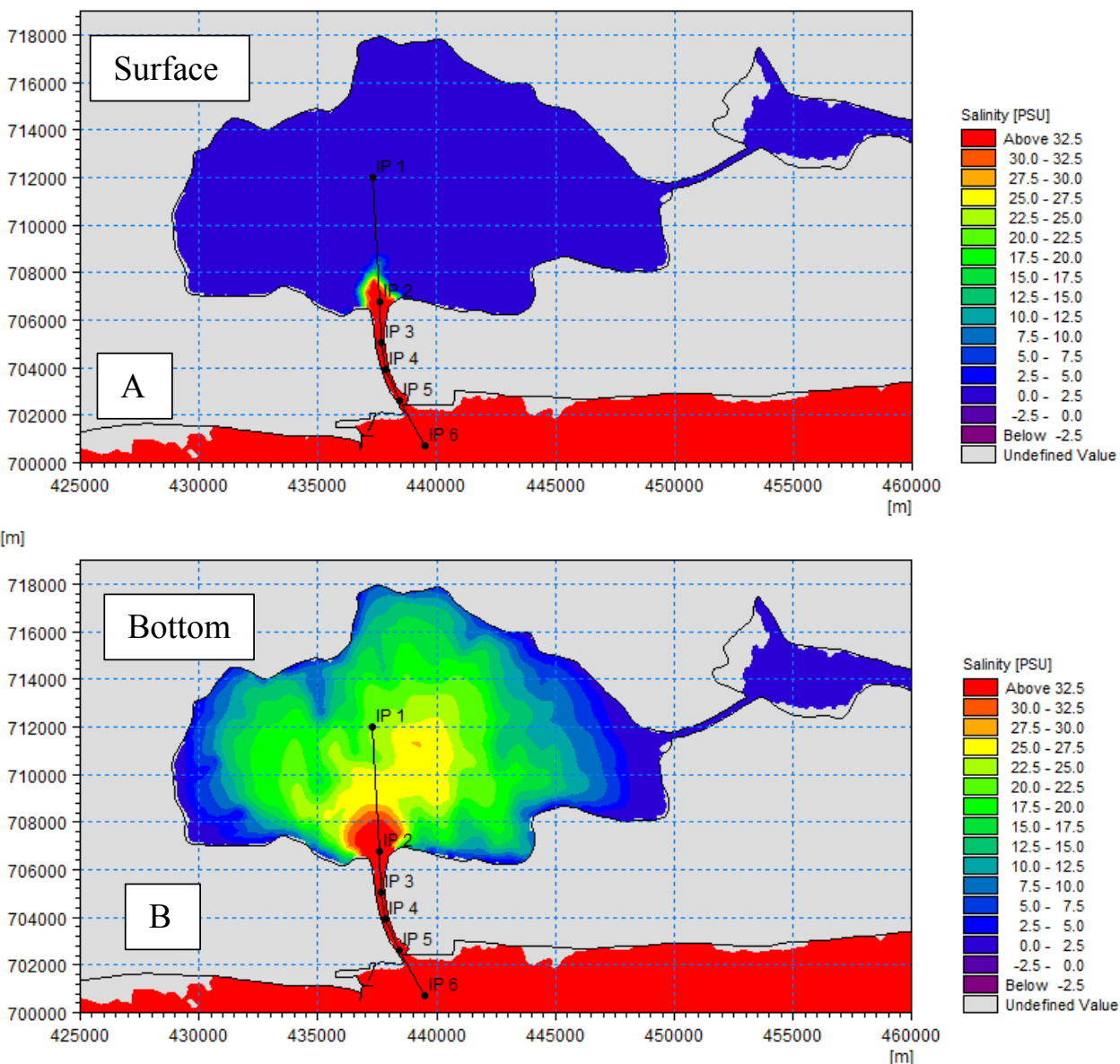

Figure 9: Salinity fields at the bottom and the surface after 3.5 days of simulation, in high water, without wind and river inputs.
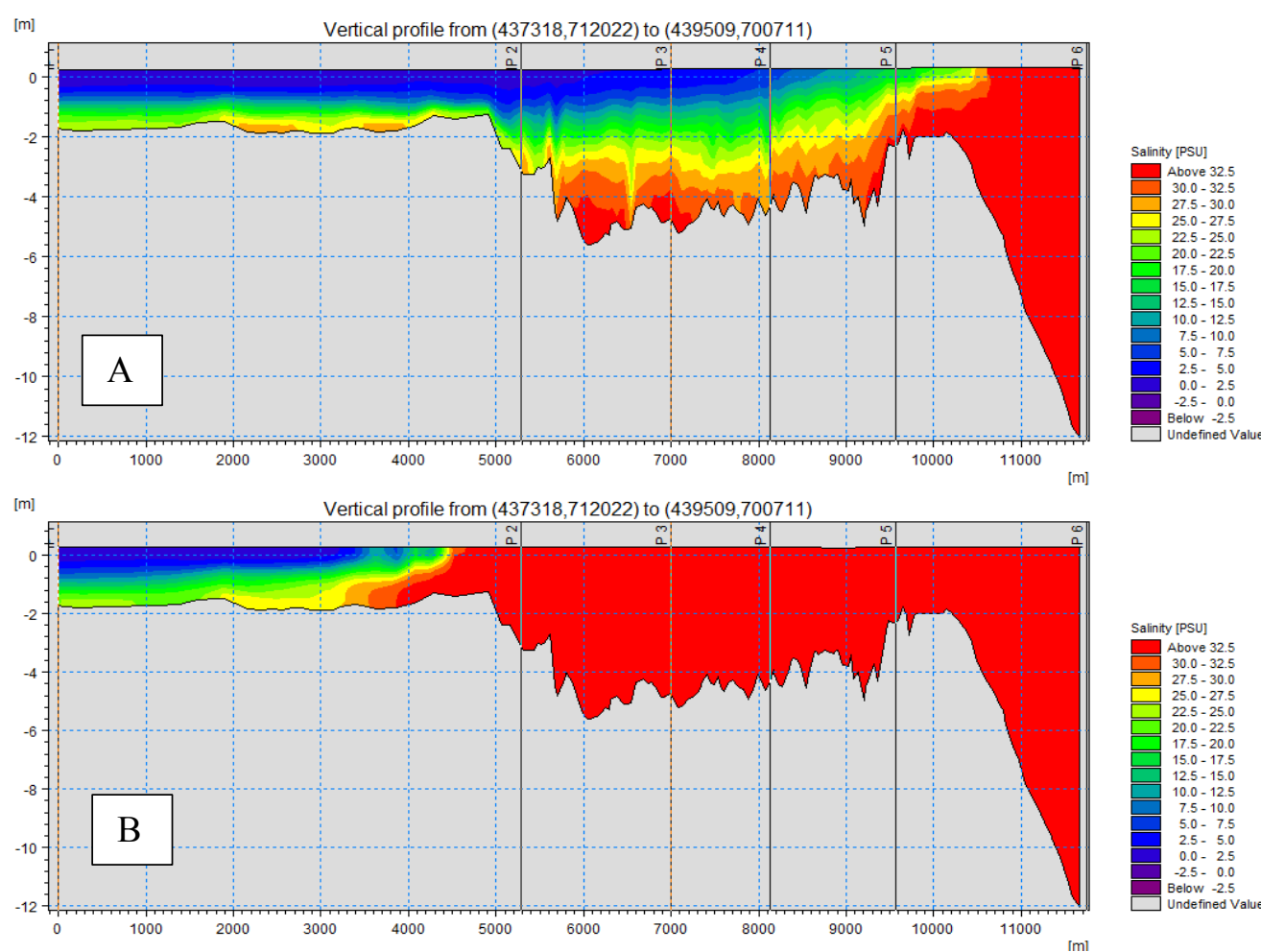

Figure 10: Cross-section of salinity concentration in $(A)$ non-turbulent and $(B)$ turbulent after 3 days of simulation, in high water period, without wind and with $1100 \mathrm{~m}^{3} / \mathrm{s}$ of fluvial inputs at Bonou. 
Different scenarios were tested according to the flow conditions of the rivers and the wind. It is assumed for this phase that the pollutant used does not react with the biological community and does not change its chemical form during the simulation time. The results of the simulations carried out (Figure 11, Figure 12 and Figure 13) show the evolution of the tracer relative concentration (initially of unit concentration, without unit) at the surface and near the bottom.

In the low water period ( $50 \mathrm{~m}^{3} / \mathrm{s}$ for So River and $20 \mathrm{~m}^{3} / \mathrm{s}$ for the Ouémé River) without wind influence, a preferential stretching of the pollutant towards the Cotonou Channel was observed on the surface. Pollutants ejected at the surface at Ganvié disperse towards the Channel of Cotonou (Figure 11A). The dispersion was slow, and only a low concentration of pollutants reached the channel. Pollutants ejected at the surface at Dantokpa disperse along the Cotonou Channel towards the Atlantic Ocean (Figure 11B). The dispersion of the ejected pollution at the bottom of the lake at Ganvié was weak (Figure 11C). In fact, the bottom water currents at Ganvié were very low which led to an accumulation of pollution at the bottom of this location. While in Dantokpa, the bottom pollution was widely dispersed both toward the interior of the lake $(72 \%)$ and to the Atlantic Ocean (28\%) (Figure 11D). The dilution of bottom pollution in Dantokpa was fast. This could be explained by high water currents at Dantokpa because of the proximity of this point to the channel of Cotonou. The dispersion of the Dantokpa bottom pollution suggests that it could be a major nutrient source for the high phytoplankton development which was observed in the middle of the lake.

The addition of the effect of a south-westerly wind of $0.5 \mathrm{~m} / \mathrm{s}$ in the low water period modified the dispersion of pollutants ejected both at the surface and at the bottom of the lake. At Ganvie the pollution at the surface spreads towards the North East of the lake (Figure 12A). The pollution at the bottom was slightly dispersed toward the north, with the major part of the pollution remaining around the Ganvié area (Figure 12C). At Dantokpa, the presence of south-westerly winds tends to rapidly disperse the pollution at the surface (Figure 12B). Part of this pollution flows towards the Cotonou Channel, while the pollution ejected at the bottom of Dantokpa was dispersed mainly towards the west of the lake, with only $20 \%$ of the pollution leaving the system through the Channel of Cotonou. In general, the presence of wind modifies the dispersion of pollutants both at the surface and at the bottom of the lake. Less than $30 \%$ of the pollution ejected was flushed from the system. The major part of the pollution sink to the bottom of the place where they were ejected or are diluted into the water column of the lake.

During the high water period ( $150 \mathrm{~m}^{3} / \mathrm{s}$ for So River and $250 \mathrm{~m}^{3} / \mathrm{s}$ for the Ouémé River) dilute the pollution ejected at the surface was dispersed much faster at Ganvié (Figure 13A) and Dantokpa (Figure 7-16B) when compared to low water period. This pollution tends to come out of the system through the Channel of Cotonou into the Atlantic Ocean. Much of the bottom pollution (60\%) at Ganvié was discharged out of the lake into the Channel of Cotonou (Figure 13C). This result indicates that the high water period favours the removal and the flushing of the accumulated pollution at Ganvié. 95\% of the bottom pollution at Dantokpa was flushed out of the lake, into the Atlantic Ocean (Figure 13D).

In general, there is an accumulation of pollution at the bottom of the lake during low water periods. This accumulation is greater as far as one moves away from the Channel of Cotonou towards the north of the lake. In fact, near the channel, the interaction between the lake water current and the tidal currents favours the dilution of the pollution and the discharge of a small part of this pollution (19\%) into the Atlantic Ocean. In the high water period, occurred the flushing of the pollution accumulated in the lake (about $73 \%$ ) into the Atlantic Ocean. This result confirms the observations made on the trophic state of Lake Nokoue which passes from eutrophic to mesotrophic during the high water period. It is important to remind here that the simulations carried out remains at the level of calibration tests, and will have to be refined depending on the tidal data covering the entire hydrological period of the lake. Existing sources of pollution around the lake will also need to be classified before the verification and validation tests of the model. 


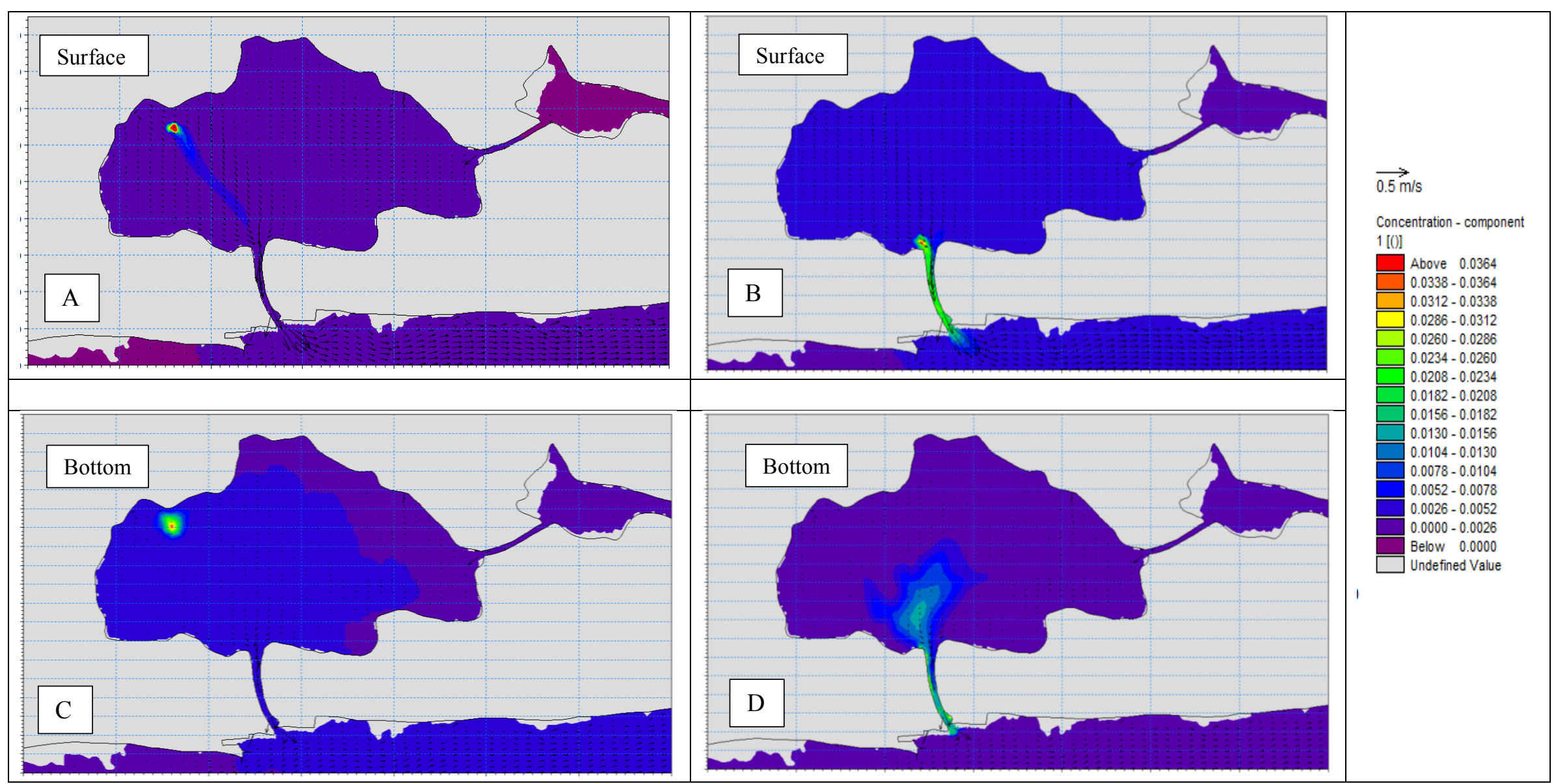

Figure 11: Relative concentration in low water period ( $50 \mathrm{~m}^{3} / \mathrm{s}$ for So River and $20 \mathrm{~m}^{3} / \mathrm{s}$ for the Ouémé River), and without wind, of a conservative tracer released continuously at Ganvié and Cotonou, at the surface and near the bottom 


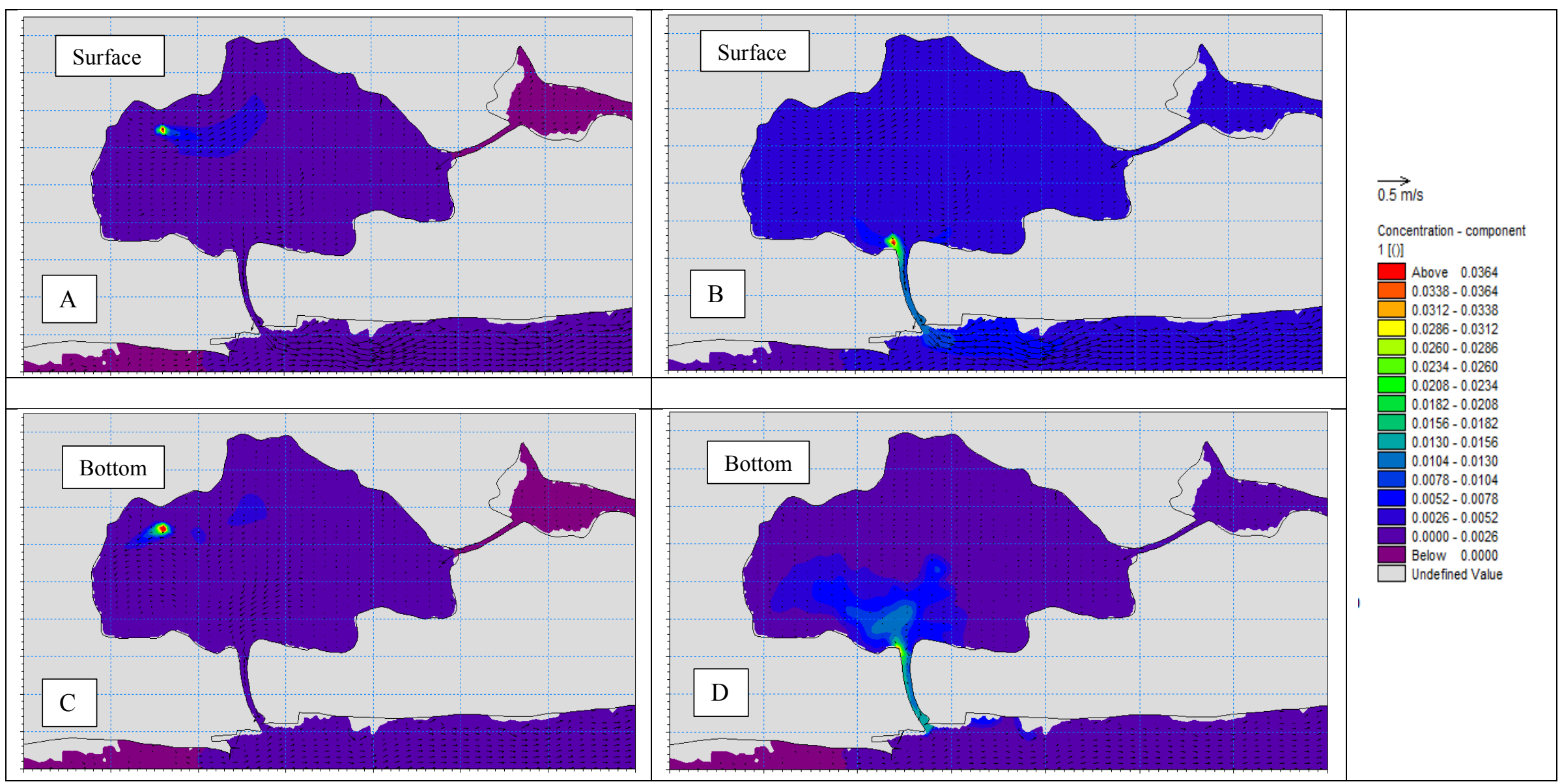

Figure 12: Relative concentration in low water period $\left(50 \mathrm{~m}^{3} / \mathrm{s}\right.$ for So River and $20 \mathrm{~m}^{3} / \mathrm{s}$ for the Ouémé River), and with wind, of a conservative tracer released continuously at Ganvié and Cotonou, at the surface and near the bottom 


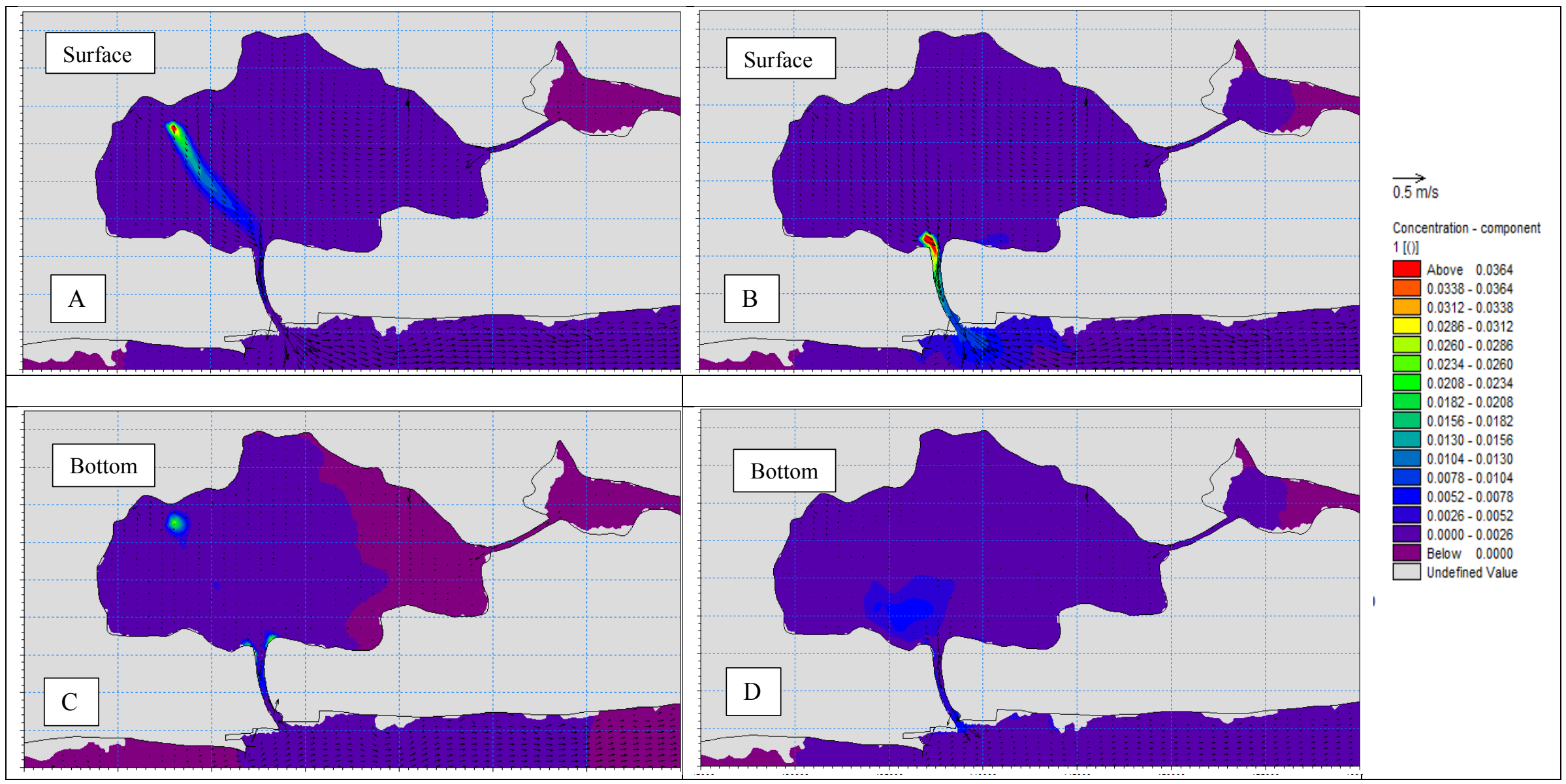

Figure 12: Relative concentration in high water period $\left(150 \mathrm{~m}^{3} / \mathrm{s}\right.$ for So River and $250 \mathrm{~m}^{3} / \mathrm{s}$ for the Ouémé River), and without wind, of a conservative tracer released continuously at Ganvié and Cotonou, at the surface and near the bottom 


\section{Reference}

Djihouessi, M. B., \& Aina, M. P. (2018). A review of hydrodynamics and water quality of Lake Nokoué: Current state of knowledge and prospects for further research. Regional Studies in Marine Science, 18, 57-67.

Fu, B., Merritt, W. S., Croke, B. F. W., Weber, T. R., \& Jakeman, A. J. (2019). A review of catchmentscale water quality and erosion models and a synthesis of future prospects. Environmental Modelling \& Software, 114, 75-97. https://doi.org/10.1016/j.envsoft.2018.12.008

Jakeman, A. J., Croke, B. F. W., \& Fu, B. (2018). Uncertainty in environmental water quality modelling: Where do we stand? In G. Mannina (Ed.), New Trends in Urban Drainage Modelling. UDM 2018. Green Energy and Technology (pp. 557-565). Cham: Springer.

Le Barbé, L., Alé, G., Millet, B., Texier, H., \& Borel, Y. (1993). Les ressources en eaux superficielles de la République du Bénin. Monographies hydrologiques ORSTOM, (11).

Zandagba, J., Moussa, M., Obada, E., \& Afouda, A. (2016). Hydrodynamic Modeling of Nokoué Lake in Benin. Hydrology, 3(4), 44. 